\title{
A comparison of corneal biomechanical properties of chronic smokers and non-smokers using the ocular response analyzer
}

\begin{abstract}
We compared the biomechanical properties of corneas in eyes of healthy chronic smokers and non-smokers. In this prospective, comparative, and cross-sectional study, 50 eyes of 50 healthy chronic smokers (Study group) and 50 eyes of 50 age-matched, healthy nonsmokers (Control group) were enrolled. The corneal hysteresis $(\mathrm{CH})$ and corneal resistance factor (CRF) were measured in two groups using the Ocular Response Analyzer (ORA). Differences in the corneal biomechanical properties were determined using an independentsamples $\mathrm{t}$ test. Urine samples were collected to measure urinary levels of cotinine. Correlations between the number of cigarettes smoked per day, smoking duration, age, and $\mathrm{CH}-\mathrm{CRF}$ values in the smokers group were also evaluated. Mean $\mathrm{CH}$ was $10.63 \pm 2.08$ (SD) $\mathrm{mmHg}$ and $10.57 \pm 1.45 \mathrm{mmHg}$ and the mean CRF was $10.53 \pm 1.81 \mathrm{mmHg}$ and $10.27 \pm 1.77$ $\mathrm{mmHg}$ in the smoker and control groups, respectively ( $\mathrm{p}>0.05)$. $\mathrm{CH}$ and $\mathrm{CRF}$ were not correlated with the number of cigarettes smoked per day, smoking duration, or age. The findings indicate that cigarette smoking does not affect corneal biomechanical parameters such as $\mathrm{CH}$ and CRF. In addition, $\mathrm{CH}$ and CRF are not affected by the number of cigarettes smoked per day, smoking duration, or age.
\end{abstract}

Keywords: cigarette smoking, corneal hysteresis, corneal resistance factor, chronic smoking, ORA
Volume 2 Issue I - 2015

\author{
Nihat Sayin, Necip Kara, Yusuf Yildirim, Hasan \\ Altinkaynak \\ Kanuni Sultan Suleyman Education and Research Hospital, \\ Turkey
}

Correspondence: Nihat Sayin, Kanuni Sultan Suleyman Education and Research Hospital, Turgut Ozal cad No I Halkal, Turkey, Tel 00905334383755,Email nihatsayin@yahoo.com

Received: December 23, 2014 | Published: January 3, 2015
Abbreviations: ORA, ocular response analyzer; $\mathrm{CH}$, corneal hysteresis; CRF, corneal resistance factor; IOPcc, cornealcompensated IOP; IOPg, goldmann-related intraocular pressure; IOP, intraocular pressure; $\mathrm{CCT}$, central corneal thickness; $\mathrm{AL}$, axial length

\section{Introduction}

Chronic smoking has negative effects on the ocular surface; chronic smokers had lower Schirmer scores in the corneas, ${ }^{1}$ a higher degree of squamous metaplasia, ${ }^{2,3}$ a higher grade of lipid layer changes in tears, ${ }^{3}$ and lower tear film break-up time compared with non-smokers. ${ }^{1-4}$ Smoking also affects tear secretion and protein components in tears. ${ }^{5,6}$ Furthermore, cigarette smoking may be harmful to the corneal endothelium. In our previous study, we found a significant decrease in the percentage of hexagonal cells in chronic smokers. ${ }^{1}$ In addition to these findings, another study showed that smoking may inhibit or suppress the triggering factors of keratoconus and lead to a decreased rate or reduced severity of keratoconus. ${ }^{7}$ All of these findings indicate that smoking influences biochemical processes and may change the biomechanics of the cornea. The Ocular Response Analyzer (ORA) (Reichert Ophthalmic Instruments) allows us to perform in vivo evaluation of corneal biomechanical parameters such as corneal hysteresis $(\mathrm{CH})$ and corneal resistance factor (CRF), using a noncontact rapid air pulse. $\mathrm{CH}$ measures the viscous damping of the cornea, and CRF is most often associated with the viscous and elastic resistance inherent to the cornea. ${ }^{8,9}$ Hafezi $^{10}$ reported that chronic smoking increases corneal rigidity in a statistically significant manner. However, this article will be the first to evaluate biomechanical properties in the corneas of chronic smokers by distinguishing objectively between smokers and nonsmokers. Thus, the purpose of the present study was to investigate the effects of chronic cigarette smoking on the corneal biomechanical parameters of healthy chronic smokers and non-smokers using the ORA.

\section{Material and methods}

\section{Study design}

This prospective and comparative study was carried out at the Ophthalmology Department of Istanbul Kanuni Sultan Suleyman Education and Research Hospital. The research adhered to the tenets of the Declaration of Helsinki, and a detailed written informed consent was taken before each individual's participation in the study.

\section{Subjects}

Included in the study group were 50 eyes of 50 healthy chronic smokers who had been smoking at least 30 cigarettes per day for at least 10 years and had no other systemic or ocular disease. As a control group, 50 eyes of 50 age-matched, healthy non-smokers were studied. None of the control subjects had actively smoked cigarettes or had a history of passive smoke exposure at home or at work in the current study. Study participants with any of the following conditions were excluded from the study: a best-corrected visual acuity less than $20 / 20$, history of contact lens use, use of any eye medications, past ocular surgery, or laser therapy, specific occupations associated with dry eye, high refractive errors, and systemic diseases such as diabetes mellitus and hypertension.

\section{Urinary cotinine concentration}

To distinguish objectively between smokers and nonsmokers, it was necessary to determine the level of cotinine in the urine. Cotinine, the major metabolite of nicotine, has a half life of 24 hours and is readily detectable in the smoker's urine even several days after the smoker has terminated smoking. Urine samples were collected in clean plastic containers to measure urinary levels of cotinine, ${ }^{11}$ and the basic technique used was based on spectrophotometric assessment at wavelength $532 \mathrm{~nm}$. Laboratory workups were performed in the 
laboratory of the Kanuni Sultan Suleyman Education and Research Hospital. The influence of diuresis on urinary cotinine concentrations was corrected using the method described by Thompson. ${ }^{12}$ Jatlow $^{13}$ have suggested the usefulness of urinary cotinine as an objective validation of the history of smoking.

\section{Examination protocol and measurements}

All participants underwent a detailed ophthalmologic examination including the following; spheric equivalent, best-corrected visual acuity, slit lamp examination, IOP measurement using pneumotonometry, dilated fundus examination, central corneal thickness (CCT) measurement with ultrasound pachymetry, and axial length (AL) measurements with the ultrasonic axial scan. After a complete ophthalmologic examination, patients with a suspicion of corneal disorder such as early keratoconus were examined, and corneal topography measurements were performed to exclude any form of keratoconus. The corneal biomechanical parameters were measured by an experienced clinician using Reichert Ocular Response Analyzer Software 3.01 while the patient was sitting comfortably in a chair located in a special room. Three replicate measurements with ORA were acquired for each eye. If poor-quality waveforms were obtained, they were deleted, and a new measurement was taken and the mean values of each parameter were used for statistical analysis. The clinician was masked in terms of study group. All measurements were performed between 9:00 am and 12:00 pm to avoid diurnal variations.

\section{Statistical analysis}

All statistical tests were performed using SPSS (Statistical Package for the Social Sciences; SPSS Inc., Chicago, IL, USA) version 16. The normality of the data was confirmed using the Kolmogorov-Smirnov test ( $p>0.05)$. Independent Student t test was used to compare variables between groups. Correlations between mean level of CH- CRF values and mean level of the other ocular factors were evaluated by Pearson's correlation. A $p$ value of $<0.05$ was considered significant.

\section{Results and discussion}

\section{Demographic findings}

In this study, 50 eyes of 50 healthy chronic smokers admitted to our department were included. As a control group, 50 eyes of 50 age-matched, healthy non-smokers were included. The mean $\pm \mathrm{SD}$ age of the included subjects was 36.28 \pm 5.91 years (range 28-48) and $35.02 \pm 5.83$ years (range 27-49 years) for the smokers group and the non- smokers group, respectively $(\mathrm{p}>0.05)$. On average, smokers smoked 16.70 \pm 8.00 (range 10-30) cigarettes per day and had been smoking for $12.20 \pm 3.01$ (range 10-20) years.). The characteristics of the two groups of subjects are shown in (Table 1). There were no statistically significant differences between the two groups with regard to gender, $\mathrm{AL}$, and CCT distributions $(p>0.05)$. Cotinine levels in the urine were $44.2 \pm 9.8 \mathrm{ng} / \mathrm{ml}$ in non-smokers and $2439 \pm 451 \mathrm{ng} /$ $\mathrm{ml}$ in smokers $(\mathrm{p}<0.05)$. These data clearly indicate that the smokers were accurately selected, because the urine cotinine concentration in nonsmokers is normally below $500 \mathrm{ng} / \mathrm{ml} .{ }^{14}$

\section{Biomechanical parameters ( $\mathrm{CH}$ and $\mathrm{CRF}$ )}

Table 2 shows the comparison of mean ORA measurements in smokers and non-smokers groups. Mean $\mathrm{CH}$ and CRF values in the eyes of chronic smokers were not significantly different from those in age-matched non-smokers $(p>0.05)$. The IOPg and IOPcc, which were measured with ORA, did not differ between the smokers and non-smokers $(p>0.05)$.

\section{Correlation analyses}

A correlation analysis was performed between the number of cigarettes smoked per day, smoking duration, age, and ORA parameters in the smokers group. The $\mathrm{CH}$ and $\mathrm{CRF}$ values were not associated with the number of cigarettes smoked per day, smoking duration, or age (Table 3). There is a strong relationship between smoking and a number of common eye diseases. Ophthalmologic disorders associated with cigarette smoking include cataract, agerelated macular degeneration, retinal ischemia, glaucoma, anterior ischemic optic neuropathy, Graves' ophthalmopathy, and tobaccoalcohol amblyopia. ${ }^{15,16}$ Cigarettes contain a number of heavy metals and toxic chemicals that may have many adverse effects on several organs, including the eye. ${ }^{17}$ Furthermore, some of these substances may have an influence on the cornea via their effects on collagen stability. Baker showed that formaldehyde which is a main toxic product of cigarette smoke, increases collagen cross-linking. ${ }^{18}$ Cigarette smoking is associated with a higher prevalence of nuclear cataract. ${ }^{19}$ Smoking also leads to a protein modification in the human lens and accelerates cataract development. ${ }^{19-21}$ Recently, another link was found between smoking and hyperopia. ${ }^{22}$ All of these demonstrate that smoking influences biochemical processes and may change the biomechanics of the cornea. ${ }^{2}$

Table I The demographic and clinical characteristics of participants

\begin{tabular}{|c|c|c|c|}
\hline Variable & Smokers & $\begin{array}{l}\text { Non- } \\
\text { smokers }\end{array}$ & p-Value* \\
\hline Eyes, $\mathrm{n}$ & $50 / 50$ & $50 / 50$ & \\
\hline Gender, n Female & 20 & & \\
\hline Male & 30 & & \\
\hline $\begin{array}{l}\text { Age, years } \\
\text { Mean } \pm S D\end{array}$ & $36.28 \pm 5.91$ & $35.02 \pm 5.83$ & \\
\hline Range & $28-48$ & $27-49$ & 0.286 \\
\hline $\begin{array}{l}\text { Spherical equivalent, } \\
\text { D Mean } \pm S D \\
\text { Range }\end{array}$ & -1.00 to 0.50 & $\begin{array}{l}-0.025 \pm 0.34 \\
-1.00 \text { to } 1.00\end{array}$ & 0.596 \\
\hline $\begin{array}{l}\text { Axial length, mm } \\
\text { Mean } \pm S D \\
\text { Range }\end{array}$ & $23.24 \pm 0.56$ & $23.15 \pm 0.69$ & 0.507 \\
\hline $\begin{array}{l}\mathrm{CCT}, \mu \mathrm{m} \\
\text { Mean } \pm \text { SD } \\
\text { Range }\end{array}$ & $\begin{array}{l}548.97 \pm 22.16 \\
520-628\end{array}$ & $\begin{array}{l}550.78 \pm 25.69 \\
515-630\end{array}$ & 0.713 \\
\hline $\begin{array}{l}\text { Cotinine, } \mathrm{ng} / \mathrm{mL} \\
\text { Mean } \pm \mathrm{SD} \\
\text { Range }\end{array}$ & $2439 \pm 45 I$ & $44.2 \pm 9.8$ & 0 \\
\hline $\begin{array}{l}\text { Number of smoking, } \\
\text { day } \\
\text { Mean } \pm S D \\
\text { Range }\end{array}$ & $\begin{array}{l}16.70 \pm 8.00 \\
10-30\end{array}$ & & \\
\hline $\begin{array}{l}\text { Smoking duration, } \\
\text { years } \\
\text { Mean } \pm S D \\
\text { Range }\end{array}$ & $\begin{array}{l}12.20 \pm 3.01 \\
10-20\end{array}$ & & \\
\hline
\end{tabular}


Table 2 Comparison of mean ORA measurements in smokers and nonsmokers groups

\begin{tabular}{llll}
\hline Variable & Smokers & Non-smokers & p-Value* \\
\hline $\mathrm{CH}, \mathrm{mmHg}$ & $10.63 \pm 2.08$ & $10.57 \pm 1.45$ & 0.864 \\
Mean $\pm \mathrm{SD}$ & $5.70-16.30$ & $7.60-13.60$ & \\
Range & & & \\
$\mathrm{CRF}, \mathrm{mmHg}$ & $10.53 \pm 1.81$ & $10.27 \pm 1.77$ & 0.473 \\
Mean $\pm \mathrm{SD}$ & $7.80-14.90$ & $6.60-13.40$ & \\
Range & & & \\
IOPg, $\mathrm{mmHg}$ & $15.92 \pm 3.46$ & $15.29 \pm 3.33$ & 0.354 \\
Mean $\pm \mathrm{SD}$ & $8.00-23.80$ & $11.00-25.50$ & \\
Range & & & 0.289 \\
IOPcc, $\mathrm{mmHg}$ & $14.61 \pm 3.15$ & $13.95 \pm 2.97$ & \\
Mean $\pm \mathrm{SD}$ & $8.70-21.80$ & $9.30-21.10$ & \\
Range & & & \\
\hline
\end{tabular}

$\mathrm{CH}$, corneal hysteresis; CRF, corneal resistance factor; IOPcc, cornealcompensated IOP; IOPg, goldmann-related intraocular pressure; ORA, ocular response analyzer; SD: standard deviation; ${ }^{*}$, independent student $\mathrm{t}$ test

Table 3 Results of correlation analyses for ORA measurements in chronic smokers

\begin{tabular}{llll}
\hline & Age $(\mathbf{y})$ & $\begin{array}{l}\text { Number of smoking } \\
(\mathbf{d})\end{array}$ & $\begin{array}{l}\text { Smoking duration } \\
(\mathbf{y})\end{array}$ \\
\hline $\mathrm{CH}$ & -0.068 & 0.189 & 0.032 \\
$\mathrm{r}$ & 0.637 & 0.189 & 0.826 \\
$\mathrm{P}$ & & & \\
$\mathrm{CRF}$ & 0.005 & 0.085 & 0.098 \\
$\mathrm{r}$ & 0.974 & 0.556 & 0.499 \\
$\mathrm{P}$ & & & \\
IOPg & -0.07 & $-0.26 \mathrm{I}$ & -0.084 \\
$\mathrm{r}$ & 0.631 & 0.067 & 0.561 \\
$\mathrm{P}$ & & & 0 \\
IOPcc & $-0.06 \mathrm{I}$ & -0.085 & 0.997 \\
$\mathrm{r}$ & 0.673 & 0.558 & \\
$\mathrm{P}$ & & & \\
\hline
\end{tabular}

A previous study showed that cigarette smoke contains glycotoxins, which are highly reactive glycation products that can rapidly induce the formation of advanced glycosylation end-products (AGEs) on proteins in vitro and in vivo and cause DNA mutations in vitro. ${ }^{23}$ However, during cigarette smoking, nitrogen oxides and nitrite are released at a high level, which also may increase collagen crosslinks. ${ }^{24,25}$ Recently, an epidemiologic study showed that the byproducts of cigarette smoke may lead to cross-linking of collagen, which in the cornea may prevent the development and progression of keratoconus. ${ }^{7}$ However, in that study patients with keratoconus were aware of the disease and may have tried to maintain a healthy lifestyle, for example, without smoking. A weakness of the study is the lack of a population control. Hafezi ${ }^{10}$ reported that the eyes of chronic smokers indicated significantly increased corneal rigidity.
Cigarette smoking represents a source of AGEs, which act similarly to the sugar aldehydes in the formation of AGEs in diabetes. ${ }^{26,27}$ Several previous studies have investigated the corneal biomechanical properties related to diabetes mellitus. ${ }^{28-31}$ Kotecha et al. ${ }^{28}$ reported that CRF was significantly greater in the eyes of diabetic patients, and that there were no significant differences in $\mathrm{CH}$ between patients with diabetes mellitus and those without diabetes mellitus. Goldich et al. ${ }^{29}$ showed that $\mathrm{CH}$ and $\mathrm{CRF}$ in the eyes of those with diabetes were significantly higher than in those without diabetes. In contrast to these studies, Sahin ${ }^{30}$ found that $\mathrm{CH}$ was significantly lower in diabetic patients, whereas CRF was not significantly different from that of control subjects. Kara $^{31}$ reported that diabetes mellitus does not affect corneal biomechanical parameters such as $\mathrm{CH}$ and $\mathrm{CRF}$ in children.

As mentioned above, there have been controversial studies published on corneal biomechanical changes and the literature includes only one study on the effects of chronic smoking on corneas using ORA $^{10}$ however, there have been no studies of corneal biomechanical parameters in chronic smokers that have distinguished this group objectively from non-smokers. In our study, we investigated the corneal biomechanical parameters such as $\mathrm{CH}$ and $\mathrm{CRF}$ in chronic smokers by measuring the amount of cotinine in the urine. Our data suggest that no differences exist in corneal biomechanical properties between chronic smokers and non- smokers. We also found that CRF and $\mathrm{CH}$ values were not associated with the number of cigarettes smoked per day, smoking duration, or age of the smoker.

\section{Conclusion}

The present study showed that the corneal biomechanical parameters such as $\mathrm{CH}$ and $\mathrm{CRF}$ of chronic smokers are similar to those of healthy non-smokers. The number of cigarettes smoked per day, smoking duration or age does not seem to be associated with $\mathrm{CH}$ and $\mathrm{CRF}$ in chronic smokers. From this point of view, further studies are needed to elucidate the exact relationship of $\mathrm{CH}$ and $\mathrm{CRF}$ to smoking and systemic diseases.

\section{Acknowledgments}

None.

\section{Conflicts of interest}

Author declares that there is no conflict of interest.

\section{References}

1. Sayin N, Kara N, Pekel G, et al. Effects of chronic smoking on central corneal thickness, endothelial cell, and dry eye parameters. Cutan Ocul Toxicol. 2014;33(3):201-205.

2. Satici A, Bitiren M, Ozardali I, et al. The effects of chronic smoking on the ocular surface and tear characteristics: a clinical, histological and biochemical study. Acta Ophthalmol Scand. 2003;81(6):583-587.

3. Altinors DD, Akça S, Akova YA, et al. Smoking Associated With Damage to the Lipid Layer of the Ocular Surface. Am J Ophthalmol. 2006;141(6):1016-1021.

4. Matsumoto Y, Dogru M, Goto E, et al. Alterations of the tear film and ocular surface health in chronic smokers. Eye (Lond). 2008;22(7):961-968.

5. Grus FH, Sabuncuo P, Augustin A, et al. Effect of smoking on tear proteins. Graefes Arch Clin Exp Ophthalmol. 2002;240(11):889-892.

6. Rummenie VT, Matsumoto Y, Dogru M, et al. Tear cytokine and ocular surface alterations following brief passive cigarette smoke exposure. Cytokine. 2008;43(2):200-208 
7. Spoerl E, Raiskup-WolfF, Kuhlisch E, et al. Cigarette smoking is negatively associated with keratoconus. $J$ Refract Surg. 2008;24(7):737-740.

8. Luce DA. Determining in vivo biomechanical properties of the cornea with an ocular response analyzer. J Cataract Refract Surg. 2005;31(1):156-162.

9. Kotecha A. What biomechanical properties of the cornea are relevant for the clinician? Surv Ophthalmol. 2007;52(Suppl 2):109-114.

10. Hafezi F. Tobacco smoking and its impact on corneal biomechanics. Invest Ophthalmol Vis Sci. 2010;51(12):6892.

11. Peach H, Morris RW, Ellard GA, et al. A simple, inexpensive urine test of smoking. IARC Sci Publ. 1986;(74):183-193.

12. Thompson SG, Barlow RD, Wald NJ, et al. How should urinary cotinine concentrations be adjusted for urinary creatinine concentration? Clin Chim Acta. 1990;187(3):289-295.

13. Jatlow $P, M c K e e S, O ’ M a l l e y ~ S S$. Correction of urine cotinine concentrations for creatinine excretion: is it useful? Clin Chem. 2003;49(11):1932-1934.

14. Jarvis MJ, Tunstall-Pedoe H, Feyerabend C, et al. Comparison of tests used to distinguish smokers from nonsmokers. Am J Public Health. 1987;77(11):1435-1438.

15. Seddon J, Fong D. Introducing "public health and the eye". Surv Ophthalmol. 2000;38(4):325.

16. Cheng AC, Pang CP, Leung AT, et al. The association between cigarette smoking and ocular diseases. Hong Kong Med J. 2000;6(2): 195-202.

17. Chiba M, Masironi R. Toxic and trace elements in tobacco and tobacco smoke. Bull World Health Organ. 1992;70(2):270-276.

18. Baker RR. The generation of formaldehyde in cigarettes--overview and recent experiments. Food Chem Toxicol. 2006;44(11):1799-1822.

19. Krishnaiah S, Vilas K, Shamanna BR, et al. Smoking and its association with cataract: results of the Andhra Pradesh Eye Disease Study from India. Invest Ophthalmol Vis Sci. 2005;46(1):58-65.

20. Pekel G, Cetin EN, Acer S, et al. Effect of chronic smoking on lens nucleus as assessed by Pentacam HR lens densitometry in young adults. Cutan Ocul Toxicol. 2014;33(2):145-149.
21. Mukesh BN, Le A, Dimitrov PN, et al. Development of cataract and associated risk factors: the Visual Impairment Project. Arch Ophthalmol. 2006;124(1):79-84

22. Stone RA, Wilson LB, Ying GS, et al. Associations between childhood refraction and parental smoking. Invest Ophthalmol Vis Sci. 2006;47(10):4277-4287

23. Cerami C, Founds H, Nicholl I, et al. Tobacco smoke is a source of toxic reactive glycation products. Proc Natl Acad Sci USA. 1997;94(25):13915-13920.

24. Paik DC, Dillon J, Galicia E, et al. The nitrite/collagen reaction: nonenzymatic nitration as a model system for agerelated damage. Connect Tissue Res. 2001;42(2):111-122.

25. Paik DC, Saito LY, Sugirtharaj DD, et al. Nitrite-induced cross-linking alters remodeling and mechanical properties of collagenous engineered tissues. Connect Tissue Res. 2006;47(3):163-176.

26. Seiler T, Huhle S, Spörl E, et al. Manifest diabetes and keratoconus: a retrospective case-control study. Graefes Arch Clin Exp Ophthalmol. 2000;238(10):822-825.

27. Kuo IC, Broman A, Pirouzmanesh A, et al. Is there an association between diabetes and keratoconus? Ophthalmology. 2006;113(2):184-190.

28. Kotecha A, Oddone F, Sinapis C, et al. Corneal biomechanical characteristics in patients with diabetes mellitus. J Cataract Refract Surg. 2010;36(11):1822-1828.

29. Goldich Y, Barkana Y, Gerber Y, et al. Effect of diabetes mellitus on biomechanical parameters of the cornea. J Cataract Refract Surg 2009;35(4):715-719.

30. Sahin A, Bayer A, Ozge G, et al. Corneal biomechanical changes in diabetes mellitus and their influence on intraocular pressure measurements. Invest Ophthalmol Vis Sci. 2009;50(10):4597-4604.

31. Kara N, Yildirim Y, Univar T, et al. Corneal biomechanical properties in children with diabetes mellitus. Eur J Ophthalmol. 2012;7:0. 